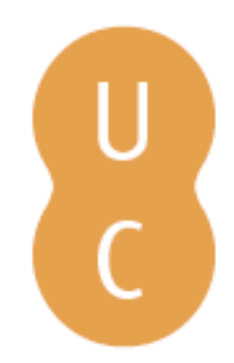

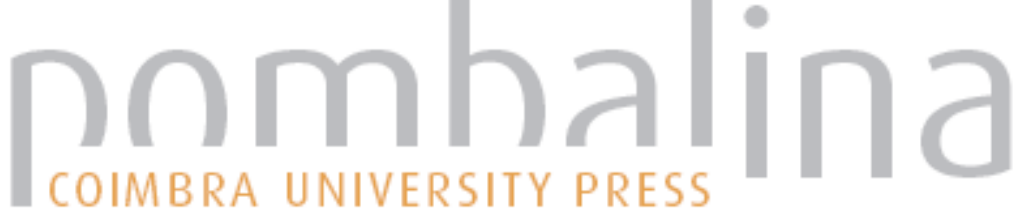

\section{Manetho and the History of Egypt}

Autor(es): $\quad$ Araújo, Luís Manuel de

Edições Afrontamento; CITCEM - Centro de Investigação

Publicado por: Transdisciplinar "Cultura, Espaço e Memória»; Centro de Estudos

Clássicos e Humanísticos; Alexandria University; Imprensa da

Universidade de Coimbra

URL

persistente:

URI:http://hdl.handle.net/10316.2/36178

DOI:

DOl:http://dx.doi.org/10.14195/978-989-26-0966-9_13

Accessed : $\quad$ 26-Apr-2023 16:02:37

A navegação consulta e descarregamento dos títulos inseridos nas Bibliotecas Digitais UC Digitalis, UC Pombalina e UC Impactum, pressupõem a aceitação plena e sem reservas dos Termos e Condições de Uso destas Bibliotecas Digitais, disponíveis em https://digitalis.uc.pt/pt-pt/termos.

Conforme exposto nos referidos Termos e Condições de Uso, o descarregamento de títulos de acesso restrito requer uma licença válida de autorização devendo o utilizador aceder ao(s) documento(s) a partir de um endereço de IP da instituição detentora da supramencionada licença.

Ao utilizador é apenas permitido o descarregamento para uso pessoal, pelo que o emprego do(s) título(s) descarregado(s) para outro fim, designadamente comercial, carece de autorização do respetivo autor ou editor da obra.

Na medida em que todas as obras da UC Digitalis se encontram protegidas pelo Código do Direito de Autor e Direitos Conexos e demais legislação aplicável, toda a cópia, parcial ou total, deste documento, nos casos em que é legalmente admitida, deverá conter ou fazer-se acompanhar por este aviso. 


\title{
MANETHO AND THE HISTORY OF EGYPT
}

\author{
LUÍS MANUEL DE ARAÚJO
}

University of Lisbon. Centro de História (University of Lisbon).

\begin{abstract}
Under the royal commission by Ptolemy II, Manetho - an Egyptian priest in the temple of Re in Heliopolis - wrote in Greek a history of Egypt (Aegyptiaca). This original text has been lost but its quotations by posterior authors such as Flavius Josephus (1st century), Julius Africanus (2nd-3rd centuries), Eusebius of Caesarea (3rd-4th centuries) and George Syncellus (8th century) help us to understand the historiographical work undergone by the ancient Egyptian scholar who, in many ways, paved the way for modern Egyptologists.
\end{abstract}

\section{MANETHO AND THE HISTORY OF EGYPT}

We owe to the Egyptian priest and scholar Manetho, contemporary of the first Ptolemaic kings, the dynastic periodization of pharaonic Egypt in thirty dynasties, still in use by Egyptologists ${ }^{1}$. Manetho was born in Sebennytos (hellenized form of the Egyptian city Tebneter or Tjebnetjer, or even Tjebnutjer, in Coptic Djemenuti, today Samannud), located at the Central Delta, where the 30th Dynasty began, the last of the long Egyptian history. Sebennytos was also the capital of the 12th province of Lower Egypt. Manetho studied at the renowned temple of Re, in Heliopolis, and collaborated in the introduction of the Sarapis cult in Alexandria, which intended to merge both Greek and Egyptian beliefs. According to Plutarch, Manetho was an adviser of the king Ptolemy I (305-285 B.C.), the Macedonian

\footnotetext{
${ }^{1}$ WADDELL, 1980: VII-XV; SALES, 2001: 538-539: SHAW, NICHOLSON, 1995: 169; THISSEN, 1980: 1180-1181.
} 
founder of the Lagid Dynasty and by request of Ptolemy II himself (285-246 B.C.) he wrote a history of Egypt.

Several literary works are ascribed to this scholar from Sebennytos, but only one of them is surely attributed to him: his history of Egypt (Aegyptiaca), whose original text has been lost, but from which we have reasonable knowledge thanks to the quotations of posterior authors: Flavius Josephus (1st century), and Christian writers such as Julius Africanus (2nd-3rd centuries), Eusebius of Caesarea (3rd-4th centuries) and George Syncellus (8th century).

Although adopting a proselytist biased perspective, the Jewish writer Flavius Josephus seems to have been able to read the works of Manetho from the original itself. He used Manetho's text as a source to write his arguments as to prove the ancientness of the Jews, having recorded:

I will begin with Egyptian documents. These I cannot indeed set before you in their ancient form; but in Manetho we have a native Egyptian who was manifestly imbued with Greek culture. He wrote in Greek the history of his nation, translated, as he himself tells us, from sacred tablets; and on many points of the Egyptian history he convicts Herodotus of having erred through ignorance ${ }^{2}$.

Flavius Josefus coincides with other pieces of information which attest that Manetho was a Hellenized Egyptian scholar who wrote in Greek his nation's history, based on the many facts he learned from the «sacred texts». To perform that huge task he would naturally had to be learned in the hieroglyphic writing (certainly seeking information in hieratic and demotic texts), as well as in the Greek language.

Sometimes the compilers of Manetho disagree among themselves in the composition of the royal lists and in the comments on the succession - monotonous at times - of kings' names and facts allegedly occurred in several reigns, as we shall see. On the other hand, the original Manetho's text only mentioned 30 dynasties, with the 30th Dynasty ending his 3rd book, the last one of his Aegyptiaca, but later on a 31st Dynasty was added, regarding the period of the Second Persian Domination, and then removed upon the arrival of Alexander.

The truth is that no one knows which material is from the Egyptian writer himself and which belongs to the work of his posterior compilers ${ }^{3}$. Flavius Josephus attempted to adjust the manethonian text to his intentions, in order to extolle the history of his people. The version of Africanus, condensed in five books written during the reign of Heliogabalus (218-222), apparently derives not directly from Manetho but from a version that appeared soon after the publication of the original text by the Sebennytos historian. Africanus's purpose

\footnotetext{
${ }^{2}$ WADDELL, 1980: 77-79.
} 
was to compare the dense manethonian chronology of the ancient nations of the Near East, particularly the pharaonic civilization, with the biblical chronology. The version from Eusebius, written in Greek during the reign of Constantine (312-337) is inspired by a Manetho's version later changed by an Helenized Jewish writer. Finally, around the year 800, the bizantine monk George, secretary of the patriarch Tarasios of Constantinople, began to write an extended history of the world since Adam to Diocletian. Among others, there is an Armenian version from the 5 th century which passed down the Greek text of Eusebius to Latin.

\section{MANETHO'S SOURCES}

Monumental royal lists with the names of kings from ancient Egypt have been preserved $^{4}$. Most of these lists date from the New Kingdom and they were certainly based on older records. Although many of these lists and records are lost today, most of them were probably still available to Manetho.

The Royal List of Abydos, which can be seen in a corridor of the temple-cenotaph belonging to Sety I, is the best preserved of such lists. In lithic support, its first king is called Meni (Menes), heading a list of 76 names, much more extensive than the number of kings mentioned in a smaller list of Ramesses II, quite damaged and found in a nearby Abydian temple, reckoning only 27 royal names. As for the list of Karnak, found in the «ancestors chamber» of the Akhmenu, in the temple of Amun, it was elaborated in the reign of Thutmose III and it can be seen today in the Louvre Museum, presenting the names of 61 kings since Sneferu (4th Dynasty) to the king that had it made in order to worship his ancestors. There is yet another list in Saqqara, carved in the tomb of an official of Ramesses II, which now bears only 47 of the original list of names, the first being that of Anedjib (1st Dynasty). Much older than these lists is another important source, the Palermo Stone dating from the 5th Dynasty, which however some authors date from the 25th Dynasty (7th century B.C. $)^{5}$. Although some of its original parts are missing, the Palermo Stone, carved on both sides, probably started with the name of king Meni, while the last name that still can be read is that of Neferirkare, the third king of the 5th Dynasty. The rest of the block with the monarchs from that dynasty is now lost but, according to Alan Gardiner, it once presented three more names: Shepseskare, Neferefre and Niuserre. Being so, this famous monument should date from the reign of this last king ${ }^{6}$.

\footnotetext{
${ }^{3}$ WADDELL, 1980: XVII.

${ }^{4}$ Monumental versions of such Egyptian royal lists can still be found either in their original places or in museums. SALES, 2011: 509-511.

${ }^{5}$ Its name derives from the fact that the larger fragment from this monument is now kept in the capital of Sicily (the remaining parts of the great original block are kept in the Cairo Egyptian Museum).

${ }^{6}$ GARDINER, 1961: 63; ARAÚJO, 2011: 34-35.
} 
Even more complete was the Royal Canon of Turin, written in hieratic text during the reign of Ramesses II and found in a tomb from Western Thebes during the 19th century. The ancient scholar that compiled the information found in the papyrus consulted several sources which probably were still available to Manetho as well. This remarkable document is now kept in the Egyptian Museum of Turin, to where it was taken after its discovery, still in a reasonable reading condition in spite of the regrettable handling that it had been object upon its shipment. The frail document was shredded into many pieces and among the nearly three hundred fragments available to us we can still identify the names of 50 kings from ancient Egypt - only a few among the many once present - along with the length of their reigns in years and months, including the names of the mythical kings from the early times. The first scholar to work on this precious source was Champollion himself?

Just like the Ramesside writer of the Royal Canon of Turin, Manetho also researched in the libraries and archives associated with the temples. Besides holding official documents of religious and cultual nature, libraries also stored papyrus regarding profane themes, from lyrical poetry to medical recopies, tales and narratives, among other subjects ${ }^{8}$. This can justify certain passages of his texts which have a more factual and anecdotic nature. The papyri were stored in those places, rolled and tied up with strings and sometimes sealed, with the possibility of being placed in niches especially carved for this purpose. The scrolls were kept in stone or ceramic containers or in small wooden boxes.

Although its construction had begun long after Manetho's lifetime, it is well known the composition of the library of the Edfu temple thanks to a list preserved on the wall of the ancient book depository room. According to this inscription we know that this deposit held the following works: the books and the large pure leather scrolls that allowed to defeat the daemons, scare the crocodiles, protect the honor, preserve the barge and sail in the great barge; the book to bring forth the king in procession; the book for conducting the cult, protecting the city, the house, the throne's white crown, the year; the book for appeasing Sekhmet; the book for hunting the lion, scaring the crocodiles, scaring the reptiles, learning all secrets of the laboratory; knowing the divine offerings in all of its details; the book of the temple's inventory; the book of capturing enemies; the book of all the fighting writings; the book of the temple's conduct; the book of instructions for decorating a wall; the book of the magical protection of the king in its palace; formula to repel the evil eye; knowledge of the periodical comings of the moon and sun as well as the control of the periodical returning of the other stars; the relation of all the sacred places and knowledge of what is found there; and all the ritual related to the go forth of the god from his temple on the festive days ${ }^{9}$.

\footnotetext{
${ }^{7}$ Certainly many studies and editions followed. See ARAÚJO, 2011: 35.

${ }^{8}$ Besides obeying to conservation purposes, to the constitution of a library in ancient Egypt was not exempt a certain ludic taste as well.

${ }^{9}$ SAUNERON, 1988: 144-145.
} 
Also in the Dendera temple dedicated to the goddess Hathor, the room designed to store the sacred books was carved with a scribe's palette on the wall, followed by a list of the several books kept in that location. The same occurred, according to the information provided by archaeological records, in the temple of Tod in Ermant, near Thebes, where the wall inscriptions tell us of the existence of a scroll regarding the entering of the god Montu in Thebes; the ritual of restoring the eye of Horus (the magical wdjat-eye); the book of offerings upon the altar of the temple of Amun; the book of Thot's festival (the god of scribes and inventor of writing); the book of the temple of Khonsu (young lunar god, son of Amun); the ritual of the victory's festival; the ritual for the birth of the god, among others. These are significant examples of the material kept in the temples, namely in the «rooms of divine writings», which were important places for archiving documents directly related to the daily life on the cultic space.

To those collections of manuscripts we can also add the libraries that we know that once existed in the late temples of Philae (dedicated to the goddess Isis), Kom Ombo (built for the double cult of Sobek and Horuer) and Esna (dedicated to Khnum), but all these libraries are in fact posterior to Manetho's activity. And, if all these temples had their own big libraries, we can only wonder how the library of the great temple of Amun in Karnak could be, since this was the largest of all the temples built in the ancient Egypt and was, indeed, available to the Sebennytos priest.

There were also private libraries, made for private owners who wished to add some classical texts to their own funerary collections, as proved by a box found near the Ramesseum containing several papyri scrolls that once belonged to a priest that lived in the Middle Kingdom.

\section{FROM EARLY TIMES TO THE OLD KINGDOM}

Since the Manetho's original text is lost, we have to follow the later versions of the Christian cronographs that historiographed the dynasties of ancient Egypt. Looking at the somehow similar texts of Africanus and Eusebius we find that Manetho, as a good Egyptian and learned scholar, began his history on the millenary pharaonic monarchy with the reigns of the gods and the «Spirits of the Dead», referring to the bau of Pe and Dep, mythical locations of the Delta, and to the bau of Heliopolis (Iunu), which are indeed the «Followers of Horus» (Shemsu-Hor). As for the allusion to the Flood, or «Universal Flood», it probably is not the work of the Egyptian priest himself, being instead a later addition of the Christian authors that quoted his work.

The Palermo Stone and the Royal Canon of Turin notice the existence of gods that ruled in Egypt, meaning the world, starting with Ptah (who in Greek versions appears as Hephaestus) followed by Re, Shu, Geb, Osiris, Seth and Horus - this is the Heliopolitan Ennead, with Re taking the place of Atum and with the reign of Horus signing the victory 
over the usurper Seth. This list also attest a typically harmonic fusion with the Memphite cosmogony of Ptah, who appears there as the first king, ending the list of divine kings with the names of Thot and Maet ${ }^{10}$.

The version of Africanus starts his cast of the historical phase with the following order:

Here is the account which Africanus gives of the dynasties of Egypt (after the Flood). 1. In succession to the spirits of the Dead, the Demigods, the first royal house numbers eight kings, the first of whom Mênês of This reigned for 62 years. He was carried off by a hippopotamus and perished. 2. Athôthis, his son, for 57 years. He built the palace at Memphis; and his anatomical works are extant, for he was a physician. 3. Kenkenês, his son, for 31 years. 4. Uenephês, his son, for 32 years. In his reign a great famine seized Egypt. He erected the pyramids near Kôchômê. 5. Usaphaidos, his son, for 20 years. 6. Miebidos, his son, for 26 years. 7. Semempsês, his son, for 18 years. In his reign a very great calamity befell Egypt. 8. Biênechês, his son, for 26 years. Total, 253 years $^{11}$.

As for the version of Eusebius, it presents the following order:

here is the account wich Eusebius gives of the Egyptian dynasties (after the Flood). In succession to the Spirits of the Dead and the Demigods, the Egyptians reckon the First Dynasty to consist of eight kings. Among these was Mênês, whose rule in Egypt was illustrious. I shall record the rulers of each race from the time of Mênês; their succession is as follows: 1. Mênês of This, with his 7 descendants - the king called Mên by Herodotus, reigned for 60 years. He made a foreign expedition and won renown, but was carried off by a hippopotamus. 2. Athothis, his son, ruled for 27 years. He built the palace at Memphis; he practised medecine and wrote anatomical books. 3. Kenkenês, his son, for 39 years. 4. Uenephês, for 42 years. In his reign famine seized the land. He built the pyramids near Kôchôme. 5. Usaphaïs, for 20 years. 6. Niebaïs, for 26 years. 7. Semempsês, for 18 years. In his reign there were many portents and a very great calamity. 8. Ubienthês, for 26 years. The total of all reigns, 252 years.

As for the Armenian version of Eusebius, besides the differences in the onomastic forms, there is mention to the fact that Herodotus called Men (Min) to the first king of Egypt $^{12}$. Athothis, the heir of Menes-Meni, may well be the Teti from the Abydo's list, founder of Memphis (Ieneb-hedj) and, regarding the other names, their relation with the Turin's list and with the Horus names that archaeology provided us, is only conjectural ${ }^{13}$.

\footnotetext{
${ }^{10}$ GRIMAL, 1988: 63.

${ }^{11}$ WADDEL, 1980: 27-29.

12 WADDELL, 1980: 29-35.

${ }^{13}$ GARDINER, 1961: 430.
} 
Surely Manetho, according to the records of his followers, does not mention the «Dynasty 0», as we conventionally call that foggy phase that preceded the 1st Dynasty initiated by Menes-Meni - and in this case this king would be no other than Horus Aha, since the identification of Menes-Meni with Narmer would place him at the end of the previous «Dynasty 0 », as today some authors $\mathrm{do}^{14}$. But the archaeological endeavors of the last decades in the Abydos area (particularly in Umm al-Qaab) revealed the names of unknown monarchs who prepared the unification. To those names we can also add the information provided by the archaeological excavations in Hierakompolis (Kom el-Ahmar).

In the text of Africanus, the 2nd Dynasty presented nine kings from Thinis:

The first was Boêthos, for 38 years. In his reign a chasm opened at Bubastus, and many perished. 2. Kaiechôs, for 39 years. In his reign the bulls, Apis at Memphis and Mnevis at Heliopolis, and the Mendesian goat were worshipped as gods. 3. Binôthris, for 47 years. In his reign it was decided that women might hold the kingly office. 4. Tlas, for 17 years. 5. Sethenês, for 41 years. 6. Chairês, for 17 years. 7. Nephercherês, for 25 years. In his reign, the story goes, the Nile flowed blended with honey for 11 days. 8. Sesôchris, for 48 years: his stature was 5 cubits, 3 palms. 9. Chenerês, for 30 years. Total, 302 years.

The Eusebius version, although smaller, is not much different from that of Africanus and only differs slightly in the names of the kings, and the Armenian version states the same, although there is a note considering the phenomenon of the Nile Flood mixed with honey nothing but a fable ${ }^{15}$. From this long onomastic list imported from Manetho, or from the texts inspired by his work, what then can we use with historical value? Just like the case of the 1st Dynasty, the royal names presented in the lists made by the compilers of the Egyptian priest do not match completely with those inscribed in the lists of Abydos regarding the 2nd Dynasty. The archaeological information allows us to list about 12 sovereigns but the manethonian list only reckons «nine kings from Thinis», and none of them has anything to do with the king Peribsen (who uncommonly took for himself the name-title of Seth) nor with the last king of that dynasty, the Horus Khasekhemwy, who promoted the stabilization of the country after a turbulent phase of rivalries ${ }^{16}$. On the other hand, we should underline a certain emphasis given to aspects related to the Lower Egypt (Delta) and the news that Binotris (who was the Banutjeren from the Abydos, Sakara and Turin's lists, or the Horus Ninetjer) decided that women «could hold royal positions». Being true, this decree just confirmed what in fact had already happened in the 1st Dynasty: the

\footnotetext{
${ }^{14}$ CLAYTON, 2004: 16; WILKINSON, 2005: 66-70; ARAÚJO, 2011: 52-53.

${ }^{15}$ WADDELL, 1980: 35-41.

${ }^{16}$ GARDINER, 1961: 431-432; ARAÚJO, 2011: 62-65.
} 
queen Merneith assumed the regency of the country during the minority of age of her son, the Horus Den ${ }^{17}$.

\section{THE OLD KINGDOM}

According to the version of Africanus, the 3rd Dynasty, which started the Old Kingdom, had nine kings, described in the following order:

1. Necherôphês, for 28 years. In his reign the Libyans revolted against Egypt, and then the moon waxed beyond reckoning, they surrendered in terror. 2. Tosorthros, for 29 years. In his reign lived Imuthês, who because of his medical skill has the reputation of Asclepios among the Egyptians, and who was the inventor of the art of building with hewn stone. He also devoted attention to writing. 3. Tyreis (or Tyris), for 7 years. 4. Mesôchris, for 17 years. 5. Sôÿphis, for 16 years. 6. Tosertasis, for 19 years. 7. Achês, for 42 years. 8. Sêphuris, for 30 years. 9. Kerpherês, for 26 years. Total, 214 years.

Meanwhile, the version of Eusebius mentions eight kings who were listed with different onomastic forms such as:

1. Necherôchis, in whose reign thje Lybians revolted against Egypt, and when the moon waxd beyond reckoning, they surrendered in terror. 2. He was succeded by Sesorthos...: he was styled Asclepios in Egypt because of his medical skill. He was also the inventor of the art of building with hewn stone, and devoted attention to writing as well. The remaining six kings achieved nothing worthy of mention. These eight kings reigned for 198 years.

As for the Armenian version of Eusebius it is practically similar ${ }^{18}$. Tosorthos is undoubtably the Horus Netjerikhet Djoser, to whom Imhotep (Imuthes) erected the funerary complex of Sakara with the Stepped Pyramid (note that a missing part of the text in the Eusebius version made disappear the name of the great royal architect). As for the nine kings mentioned by Africanus, the archaeological research only documented the existence of five names, who are also present in the list from Abydos: Djoser, Sekhemkhet, Nebka, Sanakht and Huni ${ }^{19}$.

From the existing versions that complete the lost original work of Manetho we can read in Africanus the list of kings from the 4th Dynasty, composed by «eight kings of Memphis, belonging to a different line». Those kings were:

\footnotetext{
${ }^{17}$ WILKINSON, 2005: 75-78; ARAÚJO, 2011: 61.

${ }^{18}$ WADDELL, 1980: 41-45; GARDINER, 1961: 433.

${ }^{19}$ GRIMAL, 1988: 85-89; VERCOUTTER, 1992: 257-265; WILKINSON, 2005: 94-105; ARAÚJO, 2011: 68-72.
} 
Sôris, for 29 years. 2. Suphis (I), for 63 years. He reared the Great Pyramid, wich Herodotus says was built by Cheops. Suphis conceived a contempt for the gods: he also composed the Sacred Book, wich I acquired in my visit to Egypt because of its high renown. 3. Suphis (II), for 66 years. 4. Mencherês, for 63 years. 5. Ratoisês, for 25 years. 6. Bicheris, for 22 years. 7. Sebercherês, for 7 years. 8. Thamphthis, for 9 years. Total, 277 years.

According to Eusebius, the 4th Dynasty

comprised seventeen kings of Memphis belonging to a different royal line. Of these the third was Suphis, the builder of the Great Pyramid, which Herodotus states that was built by Cheops. Suphis conceived a contempt for the gods, but repenting of this, he composed the Sacred Book, which the Egyptians hold in high esteem. Of the remaining kings no achievement worthy of mention has been recorded. This dynasty reigned for 448 years.

As for the Armenian version, it is very similar to the one of Eusebius ${ }^{20}$.

Unlike the previous dynasties, to this one is easier to establish the relation between the names of Manetho and those recorded in the royal lists, also attested on historical records: Soris is Sneferu, Suphis is Khufu (the Queops from Herodotus) and Mencheres is Menkaure (Mikerinos to Herodotus). Between Khafre and Menkaure ruled Djedefre, omitted by Africanus and Eusebius, and the remaining names are not identified with the archaeological documentation, ending the dynasty with the poorly documented reign of Shepseskaf ${ }^{21}$.

In the list handed down by Africanus, the 5th Dynasty, which revealed a strong interest on the solar cult, was composed by «eight kings of Elephantine»:

1. Usercherês, for 28 years. 2. Sephrês, for 13 years. 3. Nephercherês, for 20 years. 4. Sisirês, for 7 years. 5. Cherês, for 20 years. 6. Rathurês, for 44 years. 7. Mencherês, for 9 years. 8. Tancherês (?Tatcherês), for 44 years. 9. Onnus, for 33 years. Total, 248 years.

The version of Eusebius is smaller, followed by the Armenian version which states that the 5th Dynasty consisted of «thirty-one kings of Elephantine. Of these, the first was Othoês, who was murdered by his bodyguard. The fourth king, Phiôps, succeeding to the throne when he was six years old, reigned until his hundredth year». As we can see, Africanus mentions eight kings but lists nine, while Eusebius mixes the 5th and 6th dynasties, giving only two names for his «31 kings» ${ }^{22}$. Some correspondence can be obtained between the Egyptian names of the pharaohs of the 5th Dynasty known today and

\footnotetext{
${ }^{20}$ WADDELL, 1980: 45-49; GARDINER, 1961: 434.

${ }^{21}$ CLAYTON, 2004: 42-48; GRIMAL, 1988: 90-99; VERCOUTTER, 1992: 272-288; ARAÚJO, 2011: 72-82.

${ }^{22}$ WADDELL, 1980: 51-53; GARDINER, 1961: 435.
} 
their Hellenized versions. Note that - although Hellenized - the royal names of this dynasty maintain the final theoforic reference to the god Re (here with the typical «s» from the onomastic suffix of the Greek form), which in the case of Unas (Onnus) is well understood, because his forename is unknown, but is rather misunderstood in the case of Userkaf who didn't evoke the god Re in his name (maybe he did so in his forename), but this onomastic form corresponding to the name of the king of Upper and Lower Egypt never came to our knowledge. Africanus just mentions the length of reign of each pharaoh, omitting important events that occurred in this period, like the increment of the commercial relations with Lebanon and Nubia, as well as the construction of the solar temples in Abusir $^{23}$.

The Old Kingdom was a long period that ended with the 6th Dynasty, which, in the version of Africanus, was composed of six kings from Memphis:

1. Othoês, for 30 years: he was murdered by his bodyguard. 2. Phius, for 35 years. 3. Methusuphis, for 7 years. 4. Phiôps, who began to reign at the age of six, and continued until his hundredth year. 5. Menthesuphis, for 1 year. 6. Nitôcris, the noblest and loveliest of the women of her time, of fair complexion, the builder of the third pyramid, reigned for 12 years. Total, 203 years.

In the short version of Eusebius the list of kings from the 6th Dynasty is absent, but there is a reference to the fact that

there was a queen Nitôcris, the noblest and loveliest of the women of her time; she had a fair complexion, and is said to have built the third pyramid. These rulers (or this ruler) reigned for three years: in another copy, 204 years. Sincelus adds:

It must be noted how much less accurate Eusebius is than Africanus in the number of kings he gives, in the omission of names, and in dates, although he practically repeats the account of Africanus in the same words.

In the Armenian version of Eusebius we can read:

The 6th Dynasty. There was a queen Nitôcris, braver than all the men of her time, the most beautiful of all the women, fair-skinned with red cheeks. By her, it is said, the third pyramid was reared, with the aspect of a mountain. The united reigns of all kings amount to 203 years $^{24}$.

${ }^{23}$ GRIMAL, 1988: 99-105; VERCOUTTER, 1992: 290-310; ARAÚJO, 2011: 83-85.

${ }^{24}$ WADDELL, 1980: 53-57; GARDINER, 1961: 436. 
For the 6th Dynasty the manethonian list essentially adjusts to the historical veracity provided by archaeology and other sources, even in the detail of the attack perpetrated on the life of Othoes (Teti), and the long reign assigned to Pepi II partially coincides with the numbers of the Royal Canon of Turin, although this subject still remains controversial ${ }^{25}$.

\section{THE MIDDLE KINGDOM}

Between the troubled end of the Old Kingdom and the Middle Kingdom occurred a chaotic period of five dynasties (from the 7th to the first half of the 11th Dynasty), known as the First Intermediate Period, and the texts regarding this phase clearly show the uncertainties in that time.

According to Africanus, «the 7th Dynasty consisted of seventy kings of Memphis, who reigned for 70 days», while to Eusebius there were "five kings of Memphis, who reigned for 75 days», and the Armenian version says that the 7th Dynasty «consisted of five kings of Memphis, who held sway for 75 years». As to the mysterious 8th Dynasty, it «consisted of twenty-seven kings of Memphis, who reigned for 146 years». The version from Eusebius, as well as the Armenian text, only reckons 100 years to the 8th Dynasty. Regarding the 9th Dynasty, the text from Africanus gives unbelievable numbers, clearly adulterating the initial Manetho's text that includes «19 kings of Herakleopolis» who ruled "409 years», while the version from Eusebius only assigns 100 years and the Armenian version states that it consisted of only four kings from Herakleopolis who ruled during 100 years. These two last references seem to be more plausible. In a strange coincidence, Africanus says that the 10th Dynasty also consisted of «19 kings of Herakleopolis», although they ruled less time, in a total of 185 years. Nevertheless, the sources available today include seven kings ruling at the same time for the 9th and the 10th dynasties, of which very little is known ${ }^{26}$.

In the versions of Africanus and Eusebius, the later followed by the Armenian text, 16 monarchs are mentioned for the 11th Dynasty, although the documentation known today only allows the identification of ten of them, and it should be noted that we have scarce information about the first, king Mentuhotep Tepiaa, considered the dynasty's founder, while for the last three we have their names recorded in the Abydos list ${ }^{27}$. One of them, Mentuhotep II, responsible for the reunification of the country and for the erection of a flaring funerary complex in Deir el-Bahari, now fairly ruined, would deserve a special reference - but he's not mentioned in Manetho's list nor in those proposed by his compilers. To whom can this lapse be assigned? One fact, though, is right: the name of this king appears in the Abydos list, so Manetho should have seen it there.

\footnotetext{
${ }^{25}$ GRIMAL, 1988: 105-115; VERCOUTTER, 1992: 318-345; ARAÚJO, 2011: 85-89.

${ }^{26}$ WADDELL, 1980: 57-63; GARDINER, 1961: 437-438; GRIMAL, 1988: 188-194.

${ }^{27}$ WADDELL, 1980: 63-65; GARDINER, 1961: 438.
} 
One of the most brilliant phases in the history of the pharaonic Egypt was the Middle Kingdom, which occurred between circa 2040 (end of the 11th Dynasty) and 1750 B.C. The lists given by Africanus and Eusebius for the 12th Dynasty do not match in their kings' names nor in the duration of their reigns, and there is not a clear relation between the onomastic forms used in the version of Manetho's compilers and the Egyptian pharaonic names, starting by the founder Amenemhat I, who Africanus calls Ammanemes and Eusebius presents as Ammenemes, or even the forename of Amenemhat III, which is Lamares to the first and Lamaris to the second. The 12th Dynasty, which we know that lasted about 230 years, had only 160 years to Africanus and 245 in the version of Eusebius. The crowns of glory of this dynasty, which dictated the accomplishment of maet (Egyptian word that can be translated as balance, harmony, truth, justice, righteousness, reflection, tolerance, universal order), are best seen in agriculture, literature and art, but in the texts of Manetho's compilers we can't find any allusion to this fundamental concept of Egyptian culture. We wonder if the Christian chronographers went over this expression without giving it the due prominence or if Manetho himself didn't stress the word - in any event the priest Petosiris, who was almost a contemporary of the Sebennytos scholar, exalted in the texts of his unusual tomb at Tuna el-Gebel the exercise of good, showing a clear commitment of maetic tone in his exhortations ${ }^{28}$.

According to Africanus, the Second Book of Manetho includes in the 12th Dynasty

seven kings of Diospolis. 1. Sesonchosis, son of Ammanemês, for 46 years. 2. Ammanemês, for 38 years: he was murdered by his own eunuchs. 3. Sesôstris, for 48 years: in nine years he subdued the whole of Asia, and Europe as far as Thrace, everywhere erecting memorials of his conquest of the tribes. Upon stelae (pillars) he engraved for a valiant race the secret parts of a man, for an ignoble race those of a woman. Accordingly he was esteemed by the Egyptians as the next in rank to Osiris. 4. Lacharês (Lamarês), for 8 years: he built the Labyrinth in the Arsinoïte nome as his own tomb. 5. Amerês, for 8 years. 6. Ammenemês, for 8 years. 7. Scemiophris, his sister, for 4 years. Total, 160 years.

The version of Eusebius, as well as its subsequent Armenian text, has substancial differences, particularly in the number of years of that dynasty and in the omission of the queen Sebekneferu (Scemiophris):

The first of these, Sesonchosis, son of Ammenemês, reigned for 46 years. 2. Ammanemês, for 38 years: he was murdered by his own eunuchs. 3. Sesôstris, for 48 years: he is said to have been 4 cubits 3 palms 2 fingers' breadths in stature. In nine years he subdued the whole Asia, and Europe as far as Thrace, everywhere erecting memorials of his

\footnotetext{
${ }^{28}$ ARAÚJO, 2003: 313-340.
} 
conquest of the tribes. Upon stelae (pillars) he engraved for a valiant race the secret parts of a man, for an ignobile race those of a woman. Accordingly he was esteemed by the Egyptians as the next in rank to Osiris. Next to him Lamaris reigned for 8 years: he built the Labyrinth in the Arsinoite nome as his own tomb. His successors ruled for 42 years, and the reigns of the whole dynasty amounted to 245 years $^{29}$.

Both chronographers start the 12th Dynasty with Senuseret I, when it is well known that the founder of the dynasty was Amenemhat I, who was supposedly murdered - tragic event here connected with Amenemhat II. Then we see Senuseret III in fancy conquests and described as the builder of unheard-of monuments, and we recognize Amenemhat III in his name of Lamares (Nimaetre), which was his name as king of Upper and Lower Egypt (forename), builder of the Labirinth - a reference to the enormous buildings Amenemhat III built next to his pyramid in Hawara ${ }^{30}$.

The dynastic and chronological confusion offered by the First Intermediate Period repeats itself in the Second Intermediate Period, and Manetho himself would have experienced a frustrating difficulty in gathering information about this troubled stage of Egypt's history. The Christian cronographers solely follow the disappointing text regarding that phase, with Africanus claiming that the 13th Dynasty "consisted of sixty kings of Diospolis, who reigned for 453 years» and the 14th Dynasty "consisted of seventy-six kings of Xoïs, who reigned for 184 years». The version from Eusebius coincides in these numbers, and the Armenian text raises the confusion as it registers «seventy-six kings of Xoïs, who reigned for 484 years» ${ }^{31}$.

According to Africanus, the 15th Dynasty was composed of «Shepherd Kings», of whom he wrote:

There were six foreign kings from Phoenicia, who seized Memphis: in the Sethroite nome they founded a town, from which as a base they subdued Egypt. The first of these kings, Saïtês, reigned for 19 years: the Saïte nome is called after him. 2. Bnôn, for 44 years. 3. Pachnan (Apachnan), for 61 years. 4. Staan, for 50 years. 5. Archlês, for 49 years. 6. Aphôphis (Aphobis), for 61 years. Total, 284 years.

But to Eusebius the 15th Dynasty "consisted of kings of Diospolis, who reigned for 250 years», which is repeated by the Armenian version ${ }^{32}$. Although little or nothing can be extracted from the discrepant onomastic list made by Africanus, we know from

\footnotetext{
${ }^{29}$ WADDELL, 1980: 67-73; GARDINER, 1961: 439.

${ }^{30}$ GRIMAL, 1988: 210-225; VANDERSLEYEN, 1995: 43-113.

${ }^{31}$ WADDELL, 1980: 73-75.

${ }^{32}$ WADDELL, 1980: 91-93.
} 
archaeological sources, that the last kings of this confusing dynasty have names with clear semitic origin, like Iakub-Baal, Iakbam and Ioam $^{33}$.

For the 16th Dynasty, the text of Africanus records that «were Shepherd Kings again, 32 in number: they reigned for 518 years». But in the version from Eusebius (repeated in the Armenian version) we can read that it consisted of «kings of Thebes, 5 in number: they reigned for 190 years». For the next dynasty, the 17th, Africanus says «were Shepherd Kings again, 43 in number, and kings of Thebes or Diospolis, 43 in number. Total of reigns of the Sheperd Kings and the Theban kings, 151 years». As we can see, the pharaohs of Herakleopolis and those from Thebes-Waset are here confusingly mixed.

As for the version of Eusebius, followed by the Armenian text, it is longer but it is also not very enlightening, saying that the 17th Dynasty was composed by «shepherds and brothers: they were foreign kings from Phoenicia, who seized Memphis. The first of these kings, Saites, reigned for 19 years: the saite nome is called after him. These kings founded in the Sethroïte nome a town, from which as a base they subdued Egypt $\rangle^{34}$.

In the 16th Dynasty, the last name appearing on the list made by Egyptologists, based on more credible information (like scarab inscriptions) is Anu, which can be an innacurate refence to an unknown ruler of semitic origin, since Amu is translated as «The Asian $»^{35}$. The clash between North and South, which would lead to the reunification of the country circa the 17th century B.C., had as protagonists the last Hyksos king of the 15th Dynasty (Apopi II) and the coeval kings of the 17th Dynasty, Sekenenre Taa and Kamose, but there are no records of the battles that followed in Manetho's compilers ${ }^{36}$.

\section{THE NEW KINGDOM}

The Jewish writers interpreted Manetho's information about the Hyksos invasion as being connected with the coming of their people into Egypt and with their posterior exodus. In the classical text of Flavius Josefus, Contra Apionem (I. 15, 16, \$\$ 93-105), the Jewish author uses Manetho's text to defend his arguments regarding the antiquity of the Jews, mixing the 18th and 19th dynasties:

For the present I am citing the Egyptians as witnesses to this antiquity of ours. I shall therefore resume my quotations from Manetho's works in their reference to chronology. His

\footnotetext{
${ }^{33}$ ARAÚJO, 2011: 28.

${ }^{34}$ WADDELL, 1980: 95-97. This historical period deserved some attention in the manethonian text recovered by Flavius Josephus, with an emphasis given to the Hyksos seen as ancestors of the Jews, being the expulsion of the Asiatics related to the famous episode of the Exodus, although for the Jewish writer it wasn't pleasant to see that Manetho placed the «chosen people» as descendants from the heaps of lepers from Egypt.

${ }^{35}$ ARAÚJO, 2011: 28.

${ }^{36}$ VANDERSLEYEN, 1995: 194-199; ARAÚJO, 2011: 126-130.
} 
account is as follows: "After the departure of the tribe of Sheperds from Egypt to Jerusalem, Tethmôsis, the king who drove them out of Egypt, reigned for 25 years 4 months until his death, when he was succeeded by his son Chebrôn, who ruled for 13 years. After him Amenôphis reigned for 20 years 7 months; then his sister Amesis for 21 years 9 months; then her son Mêphrês for 12 years 9 months; then his son Mêphramuthôsis for 25 years 10 months; then his son Thmôsis for 9 years 8 months; then his son Amenôphis for 30 years 10 months; then his son Ôrus for 36 years 5 months; then his daughter Acenchêrês for 12 years 1 month; then her brother Rathôtis for 9 years; then his son Acenchêrês II for 12 years 3 months, his son Harmaïs for 4 years 1 month, his son Ramessês for 1 year 4 months, his son Harmessês Miamûn for 66 years 2 months, his son Amenôphis for 19 years 6 months, and his son Sethôs, also called Ramessês, whose power lay in his cavalry and his fleet. This king appointed his brother Harmaïs viceroy of Egypt, and invested him with all the royal prerogatives, except that he charged him not to wear a diadem, nor to wrong the queen, the mother of his children, and to refrain likewise from the royal concubines. He then set out on an expedition against Cyprus and Phoenicia and later against the Assyrians and the Medes; and he subjugated them all, some by the sword, others without a blow and merely by the menace of his mighty host. In the pride of his conquests, he continued his advance with still greater boldness, and subdued the cities and lands of the East. When a considerable time had elapsed, Harmaïs who had been left behind in Egypt, recklessly contravened all his brother's injunctions. He outraged the queen and proceeded to make free with the concubines; then, following the advice of his friends, he began to wear the diadem and rose in revolt against his brother. The warden of the priests of Egypt then wrote a letter which he sent to Sethôsis, revealing all the details, including the revolt of his brother Harmaïs. Sethôsis forthwith returned to Pêlusium and took possession of his kingdom; and the land was named Aegyptus after him. It is said that Sethôs was called Aegyptus, and his brother Harmaïs, Danaus ${ }^{37}$.

Of the confusing amalgam of names taken by Flavius Josephus from Manetho's original it seems possible to establish a parallel with the true succession of known monarchs of the 18th Dynasty (although the text also includes kings from the 19th Dynasty). So, leaving aside the proposed dates, mostly anomalous, we can recognize Tethmosis, who expelled the Hyksos from Egypt, the last king of the 17th Dynasty, as being Kamose, succeded by Ahmose, founder of the 18th Dynasty (here Chebron). Then comes Amenhotep (in the hellenized and distorted form of Amenophis), who in fact ruled for about twenty years, followed by the perplexing presence of a woman in the throne, Amessis - it is Hatshepsut (during 21 years and 9 months, which corresponds to the length of reign of the pharaoh-queen). It is interesting to note that the name of Hatshepsut doesn't appear on the official royal lists. Therefore Manetho had to obtain this information from other sources: maybe he could read some inscriptions in Karnak or Deir el-Bahari or in any other place where the name of the queen was not erased. Then are presented several names out

\footnotetext{
${ }^{37}$ WADDELL, 1980: 101-105.
} 
of their normal order, but to which we can admit the correspondence of Thutmose I (Mephres), Thutmose II (Mephramithosis) and Thutmose III (Thmosis). This adulteration may have come from the Jewish writer, as Manetho had available in the several royal lists the correct order of the pharaohs succession.

For the second half of the 18th Dynasty it makes sense to see in Amenophis the vigorous fighter which was Amenhotep II and, leaping through the void that is the absence of Thutmose IV, the Pharaoh Orus who, having ruled «during 36 years and 5 months» adjusts to Amenhotep III. Then, all is complicated by the flood of names and dates, which again include a woman in the throne, one Acencheres, suggesting, who knows, the presence of the influent Nefertiti who was perpetuated in a certain oral tradition - being so, one of the final names of the dynasty would be that of the heretic Akhenaton, but again he is not mentioned in any official royal list. Then we get to Harmais, who is Horemheb, with the unusual length of reign of «4 years and 1 month» instead of the extended number of years in which he effectively ruled (about thirty years). Without any dinastic division suggested in the text from Josefus, we can admit that Ramesses is Ramses I, founder of the 19th Dynasty, who ruled little over a year, giving place to his son Sety I (absent here) and then to the great Ramesses II (Harmesses Miamun), who in fact ruled «during 66 years and 2 months» approximately. The ending of the dynasty is here somehow confusing: the strange Amenophis could be Merenptah, Sethos could be Sety II, leaving aside the aberrant irruption of a new Harmais.

Josephus uses the information from Manetho accordingly to his convenience, using from the original text what interested him the most. When the story of the Egyptian writer contradicts his opinions he then diminishes it and disallows it:

Up to this point he followed the chronicles: thereafter, by offering to record the legends and current talk about the Jews, he took the liberty of interpolating improbable tales in his desire to confuse with us a crowd of Egyptians, who for leprosy and other maladies had been condemned, he says, to banishment from Egypt.

And as for the thorny case of Moses and the Exodus, Josephus resolves the issue in this way:

It remains for me to reply to Manetho's statements about Moses. The Egyptians regard him as a wonderful, even a divine being, but wish to claim him as their own by an incredible calumny, alleging that he belonged to Heliopolis and was dismissed from his priesthood there owing to leprosy. The records, however, show that he lived 518 years earlier, and led our forefathers up out of Egypt to the land which we inhabit at the present time.

Clearly, the «records» from Josephus «showing» the life of Moses are those from the Bible, which naturally he follows without discussion, helping himself with the manethonian text to reinforce his ideas. 
According to Sincelus, who quotes Africanus, the 18th Dynasty had 16 kings from Diospolis:

The first of these was Amôs, in whose reign Moses went forth from Egypt, as I here declare; but, according to the convincing evidence of the present calculation it follows that in this reign Moses was still young. The second king of the 18th Dynasty, according to Africanus, was Chebrôs, who reigned for 13 years. The third king, Amenôphthis, reigned for 24 (21) years. The fourth king (queen), Amensis (Amersis), reigned for 22 years. The fifth, Misaphris, for 13 years. The sixth, Misphragmuthôsis, for 26 years: in his reign the flood of Deucalion's time occurred. Total, according to Africanus, down to the reign of Amôsis, also called Misphragmuthôsis, 69 years. Of the lenght of the reign of Amôs he said nothing at all. 7. Tuthmôsis, for 9 years. 8. Amenophis, for 31 years. This is the king who was reputed to be Memnôn and a speaking statue. 9. Orus, for 37 years. 10. Acherrês, for 32 years. 11. Rathôs, for 6 years. 12. Chebrês, for 12 years. 13. Acherrês, for 12 years. 14. Armesis, for 5 years. 15. Ramessês, for 1 year. 16. Amenôphath (Amenôph), for 19 years. Total, 263 years.

But in the version from Eusebius, the 18th Dynasty consisted of 14 kings, also from Diospolis:

The first of these, Amôsis, reigned for 25 years. 2. The second, Chebrôn, for 13 years. 3. Ammenôphis, for 21 years. 4. Miphrês, for 12 years. 5. Misphragmuthôsis, for 26 years. Total from Amôsis, the first king of this 18th Dynasty, down to the reign of Misphragmuthôsis amounts, according to Eusebius, to 71 years; and there are five kings, not six. For he ommited the fourth king, Amensês, mentioned by Africanus and the others, and thus cut off the 22 years of his reign. 6. Tuthmôsis, for 9 years. 7. Amenôphis, for 31 years. This is the king who was reputed to be Memnôn and a speaking statue. 8. Ôrus, for 36 years (in another copy, 38 years). 9. Achenchersês (for 12 years). (Athôris, for 39 years (?9).) (Cencherês) for 16 years. About this time Moses led the Jews in their march out of Egypt. (Syncellus adds: Eusebius alone places in this reign the exodus of Israel under Moses, although no argument supports him, but all his predecessors hold a contrary view, as he testifies.) 10. Acherrês, for 8 years. 11. Cherrês, for 15 years. 12. Aramaïs, also called Danaus, for 5 years: thereafter, he was banished from Egypt and, fleeing from his brother Aegyptus, he arrived in Greece, and, seizing Argos, he ruled over the Argives. 13. Ramessês, also called Aegyptus, for 68 years. 14. Ammenôphis, foe 40 years. Total, 348 years.

In conclusion, Eusebius gives the 18th Dynasty 85 more years than the version of Africanus. As for the Armenian version, it follows that from Eusebius, with the same confusion regarding names and duration of reigns ${ }^{38}$.

\footnotetext{
${ }^{38}$ WADDELL, 1980: 111-119; GARDINER, 1961: 443-444.
} 
The 19th Dynasty consisted of seven (six) kings of Diospolis:

1. Sethôs, for 51 years. 2. Rapsacês, for 61 (66) years. 3. Ammenephthês, for 20 years. 4. Ramessês, for 60 years. 5. Ammenemnês, for 5 years. 6. Thuôris, who in Homer is called Polybus, husband of Alcandra, and in whose time Troy was taken, reigned for 7 years. Total, 209 years. This is said by Africanus, because in the version of Eusebius this dynasty had only five kings: 1. Sethôs, for 55 years. 2. Rampsês, for 66 years. 3. Ammenephthis, for 40 years. 4. Ammenemês, for 26 years. 5. Thuôris, who in Homer is called Polybus, husband of Alcandra, and in whose reign Troy was taken, reigned for 7 years. Total, 194 years.

The Armenian version essentially follows the previous list, although it gives Amenephtis only 8 years, much less than the 40 years given by Eusebius. ${ }^{39}$ Here we can easily identify the Pharaoh Sety I in the form of Sethos, although he only ruled about 12 years, and the sumptuous Ramesses II appears in the ambiguous form of Rapsases (61 years) and as Ramesses (60 years), being that one of them shouldn't be here. The version from Eusebius deserves more credit (even with the strange presence of the $p$ in the name Ramses) with his 66 years, according to what we know today. Meanwhile, nothing is said about the campaigns of Sety I and Ramesses II in the Syria-Palestine, although many descriptions of battles were available to Manetho on the walls of many Egyptian temples which he undoubtedly visited when elaborating his Egyptian history, nor there is any allusion to the reign of Merenptah ${ }^{40}$.

Contrasting with the information given to other less important dynasties, the Third Book of Manetho, quoted by writers who studied his work, is scarce in information for the 20th Dynasty. To Africanus it «consisted of 12 kings of Diospolis, who reigned for 135 years». To Eusebius the duration of the dynasty was about 178 years, while in the Armenian version 172 years were registered ${ }^{41}$. In fact, none of these dilated numbers are correct: the 20th Dynasty lasted about 115 years, since 1186 B.C. (beginning of the reign of Sethnakht, founder of the dynasty) to 1070 B.C. (time of the disappearance of Ramesses XI), including ten kings, amongst them the last great sovereign of Egypt, Ramesses III. This monarch left many traces of his long reign, starting with his great funerary temple of Medinet Habu, where Manetho surely collected information for his history of Egypt - so we can naturally conclude that the later Christian chronographers abbreviated the text regarding the 20th Dynasty, for reasons that escape us. Therefore, there are no records of the victories achieved by Ramesses III against the «Sea People», which are largely described and well illustrated in Medinet $\mathrm{Habu}^{42}$.

\footnotetext{
${ }^{39}$ WADDELL, 1980: 149-153.

${ }^{40}$ VANDERSLEYEN, 1995: 493-570; ARAÚJO, 2011: 166-180.

${ }^{41}$ WADDELL, 1980: 153-155; GARDINER, 1961: 446.

${ }^{42}$ VANDERSLEYEN, 1995: 591-650; ARAÚJO, 2011: 180-188.
} 


\section{THE FINAL MILLENNIUM}

After the collapse of the New Kingdom, the Third Intermediate Period begins with the 21st Dynasty (1070-945 B.C.), which in the text of Africanus was composed by seven kings of Tanis.

1. Smendês, for 26 years. 2. Psusen(n)ês (I), for 46 years. 3. Nephercherês (Nephelcherês), for 4 years. 4. Amenôphthis, for 9 years. 5. Osochôr, for 6 years. 6. Psinachês, for 9 years. 7. Psusennês (II) (Susennês), for 14 years. Total, 130 years ${ }^{43}$.

Of the recorded names some are recognizable by approximation, such as in the case of the dynasty's founder, who appears in its hellenized form of Smendes, corresponding to the Egyptian name Nesubanebdjed, followed by Psusennes (Pasebakhaenniut in Egyptian form), the strange Amenophis in the list (Amenemope), and Psinaches, which can only be Siamon. For the 21st Dynasty a total of 130 years is given, a number that shouldn't be far from reality. The version from Eusebius and the Armenian one agree with the list and with the number of years for this dynasty, which was committed to the building of large buildings in Tanis, although those activities are not mentioned here ${ }^{44}$.

The doubts detected on the list made by Africanus for the 22nd Dynasty, from Libyan origin and derived from Bubastis (in the Oriental Delta), say much about the difficulty of Manetho himself in compiling the information he possessed on this troubled phase of the Egyptian history. According to the register of Africanus, the 22nd Dynasty «consisted of nine kings of Bubastus»:

1. Sesônchis, for 21 years. 2. Osorthôn, for 15 years. 3, 4, 5. Three other kings, for 25 (29) years. 6. Takelothis, for 13 years. 7, 8, 9. Three other kings, for 42 years. Total, 120 years. The version of Eusebius, followed by the Armenian one is briefer: 1. Sesônchôsis, for 21 years. 2. Osorthôn, for 15 years. 3. Takelôthis, for 13 years. Total, 49 years» ${ }^{45}$.

Until this day the doubts about these reigns persist, because we know of 11 kings instead of 9 proposed by Africanus, who starts the dynasty with the Pharaoh Chechonk, whose name is not far from the original Egyptian form, registered in the Bible as Chichak, recognizing also other names like Osorkon and Takelot. There is no reference to the attack led by Chechonk I in Palestine from where he brought a huge loot ${ }^{46}$.

The 23rd Dynasty appears in the version of Africanus with four kings of Tanis:

\footnotetext{
${ }^{43}$ WADDELL, 1980: 155-157; GARDINER, 1961: 447.

${ }^{44}$ KITCHEN, 1986: 262-286; ARAÚJO, 2011: 190-196.

${ }^{45}$ WADDELL, 1980: 159-161; GARDINER, 1961: 448.
} 
1. Petubatês, for 40 years: in his reign the Olympic festival was first celebrated. 2. Osorchô, for 8 years: the Egyptians call him Hêraclês. 3. Psammûs, for 10 years. 4. Zêt, for 31 years (34). Total, 89 years. The list from Eusebius differs in the wording of kings' names and in the duration of the dynasty: 1. Petubastis, for 25 years. 2. Osorthôn, for 9 years: the Egyptians called him Hêraclês. 3. Psammûs, for 10 years. Total, 44 years ${ }^{47}$.

We can be mistaken by the allusion to the «kings from Tanis», since the new dynasty, founded by Padibastet, was based in Leontopolis (Tell el-Muqadam, in Central Delta), as a result of the succession of the 22nd Dynasty from Tanis, having subsisted until the arrival of the Nubian pharaohs of the 25th Dynasty ${ }^{48}$.

The settlement of the 25th Nubian or Kushite Dynasty in Lower Egypt led to the removal of the dynasties of Libyan origin that had shredded the Delta in their benefit and dominated over some regions to the South, having the resistance been coordinated by Tefnakht from Sais, who is traditionally included on the 24th Dynasty as its founder. Meanwhile, the epitome of Africanus states that this dynasty is composed of by only one pharaoh: "Bochchôris of Saïs, for 6 years: in his reign a lamb spoke...». But, oddly, the writer registers a length of reign of 990 years, which is unacceptable. Yet, the version of Eusebius, like the posterior Armenian text, says Bochchôris of Saïs, for 44 years: in his reign a lamb spoke. Total, 44 years $^{49}$. There is not any mention to the founder of the dynasty, Teknakht of Saïs (727-720 B.C.), only to the six years given by Africanus to Bocchoris, Greek form of the Egyptian name Bakenrenef (720-715 B.C.). As for the 990 years of the 24th Dynasty it can only be an error in the transcription from the original, and the long 44 years of reign registered by Eusebius do not make any sense ${ }^{50}$.

The manethonian versions of Africanus and Eusebius regarding the 25th Dynasty differ slightly in the names of the monarchs and in the total of years. According to Africanus, this dynasty consisted of «three Ethiopian kings» who were

1. Sabacôn, who, taking Bochchôris captive, burned him alive. And reigned for 8 years.

2. Sebichôs, his son, for 14 years. 3. Tarcus, for 18 years. Total, 40 years.

In the text of Eusebius the total of years was 44, just like the Armenian version, which is exactly the same ${ }^{51}$. Missing on the list are two kings of this Nubian Dynasty, starting with the first, Piye, who supposedly had Bakenrenef burned to death, and the last, Tanutamun,

\footnotetext{
${ }^{46}$ KITCHEN, 1986: 288-355; ARAÚJO, 2001: 647-648.

${ }^{47}$ WADDELL, 1980: 161-163; GARDINER, 1961: 449.

${ }^{48}$ KITCHEN, 1986: 338-361; ARAÚJO, 2001: 657 and 648.

${ }^{49}$ WADDELL, 1980: 165-167; GARDINER, 1961: 449.

${ }^{50}$ KITCHEN, 1986: 362-177.

${ }^{51}$ WADDELL, 1980: 167-169; GARDINER, 1961: 450.
} 
who fled to Nubia after the Assyrian invasion which culminated in the plundering of Thebes-Waset. It's not difficult to make the correspondence between Sabacoon and Shabaka, Sebichos and Shabataba (or Shebiteku), Tarcus and Taharka, but some important episodes are omitted, like the fights between the Nubian kings and the kings of the Delta, the Assyrian attacks and the assault on Thebes-Waset ${ }^{52}$.

The 26th Dynasty appears in the version of Africanus with «9 kings from Saïs», in this order:

1. Stephinatês, for 7 years. 2. Nechepsôs, for 6 years. 3. Nechaô, for 8 years. 4. Psammêtichus, for 54 years. 5. Nechaô the Second, for 6 years: he took Jerusalem, and led King Iôachaz captive into Egypt. 6. Psammuthis the Second, for 6 years. 7. Uaphris, for 19 years: the remnant of the Jews fled to him, when Jerusalem was captured by the Assyrians. 8 . Amôsis, for 44 years. 9. Psammecheritês, for 6 months. Total, 150 years 6 months». According to Eusebius the list is different: «1. Ammeris the Ethiopian, for 12 years. 2. Stephinathis, for 7 years. 3. Nechepsôs, for 6 years. 4. Nechaô for 8 years. 5. Psammêtichus, for 45 (44) years. 6. Nechaô the Second, for 6 years: he took Jerusalem, and led King Iôachaz captive into Egypt. 7. Psammuthis the Second, also called Psammêtichus, for 17 years 8. Uaphris, for 25 years: the remnant of the Jews fled to hum, when Jerusalem was captured by the Assyrians. 9. Amôsis, for 42 years. Total, 163 years.

The Armenian version, which essentially followed the one from Eusebius, gives a total of 167 years $^{53}$. It's noticeable that Manetho begins the 26th Dynasty with 3 predecessors of Psametek I (664-610 B.C.), considered to be its founder. These three characters, amongst which is Necau I (Nechau), were protected by the Assyrians and ensured, in the Delta, the fight against the Nubian pharaohs of the 25th Dynasty, but the Christian chronographers do not mention this fact. The long duration of the reign of Psametek I (Psammeticus) is well documented but the 15 years of reign of his son Necau are quite reduced here. For the rest of the dynasty we know Psametek II, Apries (Uaphris, or Uahibre in Egyptian form), Amasis (Amosis, or Ahmose in its Egyptian form) and finally Psametek III (Psammecherites in the version of Africanus). This last one is absent in the version of Eusebius, who begins the list of the 26th Dynasty with a strange Ammeris, the Ethiopian, in what can be an allusion to Tanutamani, the Nubian king from the 25th Dynasty who was defeated by the Assyrians and took refuge in Nubia. The main events of this dynasty do not appear on the list, with the exception of an allusion to the victory of Necau over the king Josia of Judah at Meggido and the arrival of Jewish refugees to the region of Apries after Jerusalem was taken by the Neo-Babylonians (and not by the Assyrians, as the versions of Africanus and Eusebius state - and probably the Manetho's original). Some notable occurrences are

\footnotetext{
${ }^{52}$ ARAÚJO, 2011: 206-210.

${ }^{53}$ WADDELL, 1980: 169-173; GARDINER, 1961: 451.
} 
not mentioned, like the growing presence of Greek elements in Egypt, the establishment of an effective navy under Necau, as well as his ambitious project for opening a canal to connect the Red Sea to the Mediterranean Sea. There is also no mention to a story told by Herodotus, according to which Phoenician sailors at Necau's service had contoured the African continent. Also, there is no record of Psametek's II victorious campaign in Nubia, or the deposition of Apries by his general Amasis ${ }^{54}$.

According to Africanus, the 27th Dynasty had eight Persian kings:

1. Cambysês in the fifth year of his kingship over the Persians became king of Egypt, and ruled for 6 years. 2. Darius, son of Hystaspês, for 36 years. 3. Xerxês the Great, for 21 years. 4. Artabanus, for 7 months. 5. Artaxerxês, for 41 years. 6. Xerxês, for 2 monyhs. 7. Sogdianus, for 7 months. 8. Darius, son of Xerxês, for 19 years. Total, 124 years 4 months.

The version from Eusebius is slightly different as it includes the information that «Magi ruled for 7 months» before king Darius, but there is no mention of Artabano, giving the dynasty a total of «120 years and 4 months» ${ }^{55}$. On the next versions that copied Manetho's text there is no reference to the Egyptian resistance against the Persian domination, nor to Darius' project for the construction of a canal in the Sinai (ancestor of the current one in Suez), not even of the Greek support in the fight against Persia, which would be fundamental for the success of the rebellion that started in the reign of Artaxerxes II and culminated with Armiteus of Saiis gaining the throne and creating the 28th Dynasty ${ }^{56}$.

Both the versions of Africanus and Eusebius, as well as the Armenian text, agree that the 28th Dynasty had only one monarch who ruled during six years. The only difference is in the writing of the name of its only king: Amyrteos (in Africanus), Amyrtaeus (in Eusebius) and Amyrtes (in the Armenian version). We do not know that much about the short reign of Amirteus, and his name is never mentioned in its hieroglyphic form in any monument, being found only in Demotic and Aramaic papyri, which were certainly available to Manetho ${ }^{57}$.

In the manethonian version of Africanus, the 29th Dynasty was composed by « 4 kings of Mendes», which were:

1. Nepheritês, for 6 years. 2. Achôris, for 13 years. 3. Psammuthis, for 1 year. 4. Nepheritês (II), for 4 months. Total, 20 years 4 months.

\footnotetext{
${ }^{54}$ GRIMAL, 1988: 456-469; ARAÚJO, 2011: 213-219.

${ }^{55}$ WADDELL, 1980: 175-177; GARDINER, 1961: 452.

${ }^{56}$ GRIMAL; 1988: 477-478; ARAÚJO, 2011: 220-221.

${ }^{57}$ WADDELL, 1980: 179; GARDINER, 1961: 452; GRIMAL, 1988: 478.
} 
But Eusebius, followed by the posterior Armenian version, says that the 29th Dynasty had «4 kings of Mendes», when in his list 5 kings appear, in this order:

1. Nepheritês, for 6 years. 2. Achôris, for 13 years. 3. Psammuthis, for 1 year. 4. Nepheritês (II), for 4 months. 5. Muthis, for 1 year. Total, 21 years 4 months ${ }^{58}$.

Of this penultimate Egyptian Dynasty we know more today about its order because we have archaeological information on its first three monarchs: Naifaurud I (Neferites), who came from Mendes, in the Delta, then Pacherienmut (Psamutis), deposed by Hakor (Achoris), who in the two lists above appears exchanged with Psamutis, and Naifaurud II (Neferites II), from whom we only know the name ${ }^{59}$.

Finally, for the last 30th Dynasty, the Manetho's compilers mark the existence of 3 kings from Sebenitos:

1. Nectanebês, for 18 years. 2. Teôs, for 2 years. 3. Nectanebus, for 18 years.

Eusebius differs in the years of reign: only 10 years for the first and 8 years for the third, the same happening in the Armenian version, being Africanus closer to reality ${ }^{60}$. There is no reference to the building activities which occurred in this dynasty, nor to the Egyptian campaigns to the south of Palestine, trying to hold the Persian advances, nor even to their decisive victory in 343 B.C., when king Artaxerxes III put an end to the last Egyptian Dynasty, with Nakhthorheb (Nectanebo II) fleeing to Nubia. The founder of the dynasty was Nakhtnebef (Nectanebo I) and his ephemeral and disastrous son and successor was Teos, the hellenized form of Djedhor, a very popular name at the time ${ }^{61}$.

\section{CONCLUSION}

Today it's not possible to fully comment the historiographical work of Manetho since the original text is lost. Because the critical appreciation of the manethonian work have to be based on the texts of posterior writers, who not always have respected Manetho's original text, contemporary readers will always have to deal with an inconsistent hermeneutics of the manethonian sources.

From Manetho we have a classical division of thirty dynasties, although not all agree with the periodization generically admitted ${ }^{62}$.

\footnotetext{
${ }^{58}$ WADDELL, 1980: 179-181; GARDINER, 1961: 452.

${ }^{59}$ GRIMAL, 1988: 478-479; ARAÚJO, 2011: 221-222.

${ }^{60}$ WADDELL, 1980: 183-185; GARDINER, 1961: 453.

${ }^{61}$ GRIMAL, 1988: 481-486; ARAÚJO, 2011: 223-225.

${ }^{62}$ MÁLEK, 1997: 6-17.
} 
It's noticeable that in the dynastic lists above mentioned the names of some kings well known today are absent. They were purely omitted and wiped off from history by political and ideological reasons. We can understand the absence of the Hyksos kings (although some of them appear in the Royal Canon of Turin), but the names of Akhenaten and the Pharaoh-Queen Hatshepsut, among others, are also missing. And because they were not recorded in the Egyptian well-known royal lists, Manetho did not include them - in this respect he was led to error by Egyptian sources, in the same way the first Egyptologists did many centuries later.

As to the value of his historiographical work, several questions are intriguing. We would expect that Manetho would develop the information concerning the history of the New Kingdom, since a great deal of documentation for this historical phase was available at that time. If it is not surprising the omission of the Amarna Period and Akhenaten, the same cannot be said concerning the absence of Horemheb.

And what about the long apologetic texts on the victories of the great kings of the New Kingdom, such as Thutmose III in Meggido, Ramesses II in Kadesh, or Ramesses III against the Sea People? Were they quoted in Manetho's original text? The cold onomastic and dynastic lists from his compilers do not allow us to read any of these episodes, and we also do not know what kind of treatment Manetho gave to the historical records available in sources such as in the Palermo Stone (and in many other identical sources now lost), where interesting historical data were recorded such as the lenghth of reign, the expeditions by land and sea, the building of palaces and temples, the production of statues and stelae, the great festivities, the height of the Nile's annual flood.

It is known that Manetho responded to a solicitation of the Lagid king and, as other Egyptian literates, he collaborated with the monarchy established in Alexandria, a city that was the great metropolis of a vast rural territory, Egypt ${ }^{63}$. We have to keep in mind that in the commission of this historical work is not by all means excluded a strong political statement. The writing of Manetho's Aegyptiaca is inserted in a climate of lively rivalry with the neighboring Seleucid kingdom, which ruled, among other territories, Syria-Palestine and the area of Ancient Mesopotamia. After all, both kingdoms were the result of the division of Alexander's empire between his generals. The foreign kings that now ruled the land of Egypt literally wanted to propagate the Egyptian history (told in Greek language) and among readers who could understand the Greek language. By extolling the revered antiquity of the land they ruled from Alexandria, Ptolemies presented themselves as the "natural» successors of the millennial pharaonic monarchy - and the same did the Seleucids in their kingdom, using the literate Babylonian priest Beroso.

Manetho served indeed the Ptolemies, and these used him - we can say that probably any other choice was left for the Sebennytos scholar but to collaborate, as many others who

${ }^{63}$ RODRIGUES, 2001: 47. 
served under the Macedonian power, like the priest and physician from Sais Udjahorresenet, or Petosiris, high priest of the god Thot, who supported the growing power of the Pharaoh Alexander - unlike one of his predecessors who was executed by the new GreekMacedonian authorities for having collaborated with the Persian enemy and for being recalcitrant to the emerging Hellenistic power in Egypt. Studying, within his possibilities, the old and millennial pharaonic monarchy through the several documents at his disposal, Manetho was also exalting the Ptolemaic royalty hidden behind the mask of the pharaohs ${ }^{64}$.

In spite of the political agenda behind his work, it is unquestionable that it owns much to the genuine study of the Egyptian sources. The thirty dynasties of the Egyptian history are presented respecting a periodization that is already sensed in the autochthonous Egyptian royal lists, where three major stages of the restoration of the national unity are already identified by key-elements such as Menes-Meni (the legendary unifier), Mentuhotep II (Middle Kingdom) and Ahmose (New Kingdom). The most remarkable accomplishment of the Manetho's work, however, lies in his historiographical approach to the Egyptian sources who never compiled a coherent history of their own country. The surviving historical records well known today (probably used by Manetho himself) show a fragmentary and ambiguous nature that proves the absence of a genuine historiography as we see it today ${ }^{65}$. In spite of that the ancient Egyptians had a strong sense of their own past, characterized by a paradoxal play of immutability and cyclic renewal, permanence and continuity. A strong sense of the past was therefore an important feature of the autochthonous culture, especially during the first millennium B.C. However the historiographical work of Manetho is only possible due to his «bilingual» culture: he had to be learned in Greek authors in order to achieve the historiographical perspective with which he regards the native Egyptian sources.

\footnotetext{
${ }^{64}$ GRIMAL, 1988: 489.

${ }^{65}$ CARREIRA, 2011: 426-427.
} 